\title{
ACQUISITION OF MOTION IN L2 ESTONIAN
}

\author{
Liis Nelis, Merilin Miljan
}

\begin{abstract}
This study focuses on the acquisition of Motion in Estonian by native English speakers. The aim was to determine how English learners of Estonian are influenced by their first language (L1) when describing Motion events in Estonian as their second language (L2). Prior studies have claimed that people develop certain ways of thinking for speaking when learning their first language which affect the acquisition of other languages (e.g. Slobin 1996, Pool, Pajusalu 2012 i.a.). In order to find out how native English speakers are influenced by their L1 when acquiring Motion in Estonian, an experiment was implemented on 22 participants (11 native English speakers and 11 native Estonian speakers) in which they were asked to write a short narrative in Estonian based on a picture book by Mayer (1969). The Motion events found in the narratives were analysed one by one. The findings suggest that L1 thinking patterns influence the intermediate learners more than the advanced or beginner learners, thus partly supporting the findings of Cadierno and Ruiz (2006) who reached a similar conclusion.
\end{abstract}

Keywords: second language acquisition, Motion event, L1 English, L2 Estonian

\section{Introduction}

Languages of the world can be divided in many ways, including on the basis of how its speakers express motion. This paper uses the typology of Talmy (2000) which classifies languages as satellite-framed and verb-framed according to the structure of the utterances produced when describing Motion ${ }^{1}$ events. Accordingly, Motion not only communicates movement, but also location: a Motion event is a "situation containing motion or the continuation of a stationary location" (Talmy 2007: 73). For example, even the simple act of lying is considered a Motion event (ibid.):

(1) 'The pencil rolled off the table.' (motion)

(2) 'The pencil lay on the table.' (location)

1 Talmy (2007: 70) uses the word 'motion' with a capital $M$ to indicate that this is a specific term referring to both 
Talmy (2000: 25) describes a basic Motion event as consisting of four components: Figure, Ground, Path, Motion. The Figure is an object which is moving or located with respect to another object, the Ground. The Path is defined as "the path followed or site occupied by the Figure object with respect to the Ground object"; Motion is seen as "the presence per se of motion or locatedness in the event", that is, it includes both move and state (ibid.). These are referred to as internal components of Motion. In addition, Talmy (2007: 73) specifies an external 'Co-event' which communicates Manner or Cause, as in (3)-(4) (examples from Eifring and Theil 2005: 15):

(3) 'The bottle floated out of the cave.'

(Manner)

(4) 'The napkin blew off the table.'

(Cause)

Thus, languages in which the Path is expressed by the main verb are verb-framed languages (henceforth V-languages) and those in which the Path is expressed by the satellite are satellite-framed languages (henceforth S-languages) (Talmy 2000: 222). The languages under study in this paper, English and Estonian, qualify as S-languages accordingly: they generally show the Path of Motion in satellites (e.g. using particles such as along, away, up, off, etc. in English) and Manner of Motion in the main verb, as in (5) and (6). In contrast, V-languages (e.g. French) express the Path of Motion in the main verb and the Manner of Motion is conveyed by additional linguistic devices or left unexpressed, as in (7).

(5) She runs down.

(English)

(6) Jaan ja Lontu kukkusid ojja.

(Estonian)

Jaan.Nom and Lontu.Nom fall.PST.3PL stream.ILL

'Jaan and Lontu fell into the stream.' (Pool, Pajusalu 2012: 160)

(7) Elle descend en courant.

(French)

She.NOM descend.PRS.3SG by run.GERUND

'She descends by running.' (Hickmann, Hendriks 2010: 191)

When acquiring a second language (L2), we must adapt our understanding of expressing these Motion events to the conditions of the new language and acquire an entirely different set of rules and even a different way of thinking (Slobin 1996). For example, one may need to re-learn which information is expressed as backgrounded and which as foregrounded. Since this Slobin's (1996) idea of "thinking for speaking", much research has been carried out on the acquisition of motion but with controversial results, especially in L2 research. Cadierno and Ruiz (2006), for example, show that the thinking patterns of one's first language (L1) play a role in the narratives of adult L2 learners when expressing Path of Motion, but considerably less so in advanced learners than in the initial or intermediate stages of one's L2. The results of Navarro and Nicoladis (2005) show that English (S-language) speakers of proficient L2 Spanish (V-language) generally acquire the Spanish typology completely, however, some elements of English are still retained in their narratives.

Only a few studies have dealt with the acquisition of Motion in Estonian as an L2, e.g. Pool and Pajusalu (2012). Their study was the first to examine two languages that are typologically similar according to Talmy, as Estonian and Russian are both satellite-framed languages. The aim was to find out how native Estonian speakers and Russian learners of L2 Estonian differ in using verbs and verbal affixes when 
describing Motion events. The results showed a noticeable difference in the verb usage among the two test groups: Russian learners of L2 Estonian used a smaller amount of different verbs than the L1 speakers of Estonian and their narratives lacked in descriptive verbs.

This study contributes to the acquisition of Motion in L2 by focusing on typologically similar languages according to Talmy's (2000) classification, i.e. satellite-framed languages, English and Estonian. Yet according to the genetic affiliation, these languages belong to two different language families: Estonian is a Finnic language from the Uralic family and English is a Germanic language from the Indo-European family. Thus the ways in which these two languages express satellites are different (see section 2 for a description) and provide an interesting case to explore. More specifically, the aim is to examine how adult native speakers of English, a language with virtually no inflectional morphology, express Motion in L2 Estonian, a language with a rich inflectional system.

\section{Expressing Motion in Estonian and in English}

\subsection{Estonian}

According to Talmy's (2000) typology of motion expressions, Estonian would qualify as an S-language, because it expresses the Manner of Motion in the main verb and Path of Motion in the satellites. These satellites mainly include nouns marked by locative case markers or postpositions indicating location that may be marked by locative case-markers (Erelt et al. 1993: 138). Estonian has three grammatical and 11 semantic cases. The latter have a subgroup of six locative cases, which in turn are divided into interior and exterior locative cases. There are three interior locative cases in Estonian: illative (8), inessive (9) and elative (10) (see Erelt 2003).

(8) autosse (car.ILL)

'into the car'

(9) autos (car.INE)

'inside the car'

(10) autost (car.ELA)

'from inside the car'

Although usually marked with the ending -sse, some nouns in the illative case also have preferred short forms, as in (11) and (12). Nouns in the inessive case end in -s, as seen in (9), and the elative case is marked with the ending -st, as shown in (10).

(11) pargisse (park.ILL) - parki (park.ILL)

'into the park'

(12) majasse (house.ILL) - majja (house.ILL)

'into the house'

The Estonian language distinguishes between three exterior locative cases: allative (13), adessive (14) and ablative (15). The characteristic endings of words in these cases are respectively -le, $-l$, and -lt (see Erelt 2003). 
(13) autole (car.ALL)

'onto the car'

(14) autol (car.ADE)

'on the car'

(15) autolt (car.ABL)

'from the car'

There are only a few prepositions in Estonian, which means that a common way to express Motion is by using locative postpositions (see, e.g., Pajusalu et al. 2013, Taremaa 2013). Such postpositions include words like alla, all, sisse, sees etc., as in (16)-(19), and their NP complement has to occur in the genitive (Erelt et al. 1993: 68-69; 76).

(16) laua alla (table.gen under.ILL)

'under the table'

(17) laua all (table.GEN under.INE)

'under the table'

(18) lïva sisse (sand.GEN inside.ILL)

'into the sand'

(19) lïva sees (sand.gEN inside.INE)

'inside the sand'

Thus, Estonian uses both case-marked nouns and postpositions which may also decline for case. As a result, for some words there are three options to choose from: e.g. the noun maja can occur in long and short form of illative, majasse and majja, respectively (see 20), and one can also use the noun together with a postposition, maja sisse, as in (21). It is the postposition in example (21) which is now marked by illative, and the noun complement occurs in genitive.

(20) majasse (house.ILL) - majja (house.ILL)

'into the house'

(21) maja sisse (house.GEN inside.ILL) - majasse (sand.ILL)

'into the house'

\subsection{English}

English also conveys the Manner of Motion in the main verb and leaves the Path of Motion to be expressed with satellites to the verb. As opposed to Estonian, English does not have locative cases, making prepositions the most common satellites for conveying place (position and movement) (Eastwood 2002: 290). Prepositions of position include 'inside', 'under', 'next to', 'close to' and many more, as illustrated below (examples from Eastwood 2002: 290):

(22) There are some people inside the café.

(23) There is a dog under the table.

(24) The man is sitting next to the woman. 
(25) Their table is close to the door.

Prepositions of movement include, e.g. 'up', 'down', 'through', 'out of', etc., as in (26)-(28).

(26) She is going up the steps and he is coming down the steps.

(27) The road goes through a tunnel.

(28) The lorry is coming out of the tunnel.

On some occasions, English also uses Latinate words such as 'to ascend', 'to descend' and 'to enter'. When using these borrowed verbs, English acts as a V-language, expressing the Path of Motion in the main verb and the Manner of Motion in additional means or not at all. Likewise, Estonian has verbs like sisenema 'to enter', tõusma 'to arise', laskuma 'to descend'2. This illustrates the relativity of Talmy's (2000) theory, as pointed out by Hickmann and Hendriks (2010: 191).

\section{Acquisition of Motion in L2 Estonian}

In order to determine how native speakers of English express Motion events in L2 Estonian, two main questions were asked: 1) Do native speakers of English and native speakers of Estonian differ in the number of Motion events they describe in their Estonian narratives; and 2) What kind of linguistic means (e.g. postpositional constructions, case forms, etc.) are most frequently used by native English speakers when expressing Path of Motion in Estonian? This question thus specifically targeted the expression of Path in a Motion event, as it determines whether a language is satellite or verb framed. The overarching question was whether, and to what extent, one's L1 thinking patterns influence their narratives in L2 Estonian.

\subsection{Method and material}

Both quantitative and qualitative data were collected for this study. For obtaining qualitative data, this study followed numerous other studies about the acquisition of Motion by implementing a one-on-one experiment based on Mayer's (1969) picture book "Frog, where are you?" (see, e.g., Cadierno, Ruiz 2006, Pool, Pajusalu 2012, Slobin 1996 i.a.). The book (see Appendix) consists of 24 consecutive pictures, telling the story of a boy who comes across different animals in the woods when trying to find his frog. The participants of this study were asked to write a narrative based on the pictures found in the book. Quantitative data was collected via a short semi-structured questionnaire and the cloze test (only required from the English participants). The questionnaire was designed to collect background information on the participants, including the length of their studies of Estonian (only asked in the questionnaires for the experimental group). This study does not account for the effects of other foreign languages spoken by the experimental group that may also influence the expression of Motion events in Estonian. The participants received the questionnaire in their native language. The cloze test comprised of an

2 Thanks to the anonymous reviewer for drawing our attention to this. 
extract from the Estonian translation of the fairy tale "Punamütsike" ("Little Red Riding Hood"), in which every 8th word was deleted and replaced with a gap for the participants to fill in.

\subsection{Participants}

In total, 22 people took part in the study, 11 of whom were native speakers of English (L2 group), currently living in Estonia, and 11 native Estonian speakers (L1 group) whose narratives were used as material for comparison. The experimental group of native English speakers consisted of nine male and two female participants. This disproportionate division means that no well-founded conclusions can be drawn about the possible effect of gender on the acquisition of Motion based on the current study.

The participants were further divided into three groups according to their level of L2 Estonian: five participants were advanced users of Estonian (all male), two were intermediate (both male) and four were beginners (two male, two female). The control group consisted of nine female and three male subjects. The average age was 36 years in the L2 group and 28 years in the L1 group.

Table 1. L2 group participants' profile

\begin{tabular}{|l|l|c|c|l|}
\hline Participant & Level of Estonian & $\begin{array}{c}\text { Years lived in } \\
\text { Estonia }\end{array}$ & $\begin{array}{c}\text { Years of learning } \\
\text { Estonian }\end{array}$ & Learning method \\
\hline 1 & Advanced & $1-5$ & 2 & Independent \\
\hline 2 & Advanced & $6-10$ & 12 & Independent \\
\hline 3 & Advanced & $10+$ & 20 & Independent \\
\hline 4 & Advanced & $1-5$ & 5 & Independent \\
\hline 5 & Advanced & $6-10$ & 8 & Independent \\
\hline 6 & Intermediate & $10+$ & 14 & Independent \\
\hline 7 & Intermediate & $10+$ & 17 & Independent \\
\hline 8 & Beginner & $1-5$ & 4 & Formal instruction \\
\hline 9 & Beginner & $10+$ & 4 & Formal instruction \\
\hline 10 & Beginner & $6-10$ & 13 & Independent \\
\hline 11 & Beginner & $1-5$ & 5 & Formal instruction \\
\hline
\end{tabular}

Table 1 shows the number of years the experimental group participants had lived in the country and learned Estonian, as well as the main method they used for learning the language. The majority of participants had learned Estonian independently and the most common independent learning methods included communicating with locals, reading Estonian books and watching English TV with Estonian subtitles. 


\subsection{Procedure}

The experiment was conducted one-on-one with the participants on the campus of Tallinn University or in a cafe located in Tallinn. The cafes in which the experiments were conducted provided for a rather quiet environment, allowing for the experiment to be conducted successfully.

First, the participants were asked to answer the questionnaire. Next, they completed the cloze test which was later assessed and used to divide them into groups according to their level of proficiency in Estonian. The cloze test was used as a method of determining the level of L2 Estonian of the participants, because no other information, such as official examination results, were at hand. Then the participants were given the pictures from the 'frog story' and asked to look through them all, in order to get an overview of the story. After having familiarized themselves with the pictures, the participants were given 30 minutes to write a short story in a Word file. The exact instructions given to the participants on the 'frog story' handout were as follows:

Look through the pictures. Please write a short story in Estonian, describing the events depicted in the images. Write one to two sentences about each picture. At the bottom of the page, there is a list of nouns you may need when writing your story. You don't have to use all of the nouns and you may use more if you need to.

Similarly to other studies that used the 'frog story' (e.g. Cadierno, Ruiz 2006, Pool, Pajusalu 2012), the English group was also given a list of nouns to use in the retelling. Using dictionaries was not allowed. The whole experiment lasted about 45 minutes per person.

It may be argued that the cloze test preceding the main experiment had a priming effect, as it contained 18 Motion events, some of which were similar to the phrases one might use when describing the pictures of the 'frog story' as well. These include Motion events such as võid kukkuda ('you may fall') and läks metsa ('went into the woods'). The instructions of the 'frog story' assignment should not be considered pre-emptive to using certain constructions, as the participants were only given nouns, while verbs and other Motion-conveying parts of speech were chosen by the participants.

\subsection{Data analysis}

The data from the questionnaires was transferred into an Excel file and analysed to see whether the gender, age of onset of L2 Estonian learning or any other individual factors could be accounted for the differences seen in the narratives of the experimental group and the control group.

A maximum of 20 points could be given in the cloze test. The data collected from the tests were analysed according to the number of gaps the participants filled in correctly: participants with a score of 17 or higher were considered advanced, participants with a score of 11 to 16 were considered intermediate, and those who scored 10 or lower were considered beginners. The words written in the gaps were 
marked as correct when they were identical to the one written in the original or could replace the word in the original without making the sentence grammatically incorrect.

In order to see how native English speakers describe Motion in Estonian and whether they are influenced by their L1, the Motion events found in their written narratives of the 'frog story' were transferred to Excel and categorised according to the participants' level of Estonian. Each sentence was analysed separately, focusing on the types of constructions that the participants used, and the elements in which the narratives most extensively differed from those of the control group. For example, in order to find out which linguistic means were used the most among a certain L2 group, all postpositional constructions (e.g. puu sees 'inside the tree'), case-marked nouns (e.g. purgis 'inside the jar') and prepositional constructions (e.g. välja purgist 'out of the jar') were counted. In addition, the number of Motion events described in the narratives of native English speakers and native Estonian speakers was compared.

\section{Results and discussion}

The aim was to examine how native speakers of English express Motion events in L2 Estonian and whether English affects their expression of Motion in Estonian. In the following sections the results of the narrative lengths and Motion event quantities of the two language groups are compared, as well as the different ways in which they expressed Path. Also, the possible influence of the participants' L1 on the described Motion events is analysed and discussed in section 4.3.

\subsection{Length of narratives and number of Motion events}

The average narrative length among the L2 group was 379 words, while the average word count among the L1 group was 375, contradicting the findings of Pool and Pajusalu (2012) who found the narratives of the L1 group considerably longer than the narratives of the L2 group. Pool and Pajusalu (2012) attributed this length difference to the larger amount of lexical means available for the L1 speakers. In this study, the average lengths were levelled out as a result of the narratives of a few participants in the L2 advanced group, which were significantly longer than the average. When analysing each language level separately, the average narrative length was 433 words in the advanced group, 311 in the intermediate group and 194 in the beginner group.

The number of clauses that included Motion events was 31 in the L1 group and 26 in the L2 group. This finding once again counters the study of Pool and Pajusalu (2012) in which the number of Motion events expressed in the narratives of the native speakers group and the learners group was almost levelled: 21 and 22 respectively. The subjects of their study were all on the B2 level of Estonian, comparable to the advanced level in this study. In the present study, however, more than half of the L2 group was on the intermediate or beginner level, lowering the group's average due to insufficient lexical means for expressing themselves. Although the 
participants were provided with a list of nouns, they were asked to produce verb constructions, adjectives and other parts of the sentence on their own which led to a number of beginner level participants often omitting parts of phrases (e.g. konn ei ole puu 'frog is not tree' instead of konn ei ole puu otsas 'frog is not in the tree'). The same issue prevails when focusing on the number of Motion events found in each learner group separately: on average, 32 Motion events were found in the advanced group, 29 in the intermediate group, and only 16 in the beginner group. Similarly to the research of Pool and Pajusalu (2012), the narratives collected for the present study also contained numerous sentences where no Motion events were expressed, as in (29), or where Motion verbs were used figuratively, as in (30).

(29) Valter ja ta koer olid nüüd märjad ja küllaltki väsinud tulutust otsingust. (L2)

'Valter and his dog were now wet and rather tired from the unfruitful search.'

(30) Koer Robi otsustas Primadonna lõhna üles võtta. (L1)

'The dog, Robi, decided to pick up the scent of Primadonna.'

In example (29), no acts of movement or the continuation of a stationary location are conveyed. The participant simply described the physical and emotional state of the characters. In (30), the participant used the phrase üles võtta ('to pick up') which would otherwise be interpreted as a Motion event, but in the given context there is no actual movement taking place.

The following examples illustrate sentences that contained clauses with at least one Motion event:

(31) Ootamatult mullamutt hïpab august välja,ja poiss ehmub. (L2) (pro hüppab)

'Unexpectedly, the mole jumps out of the hole and the boy is startled.'

(32) Naissoost hirv tulijärskult, pani sarved pähe (veel kord liimiga) ja viskas poissi ${ }^{3}$ ôhku. (L2) (pro poisi)

'The female deer came from the precipice, put on its antlers and threw the boy in the air.'

In (31), one Motion event is described: hüppab ('jumps') is used as the main verb and conveys the Manner of Motion, while the postposition välja ('out of') functions as a satellite to the main verb and conveys Path of Motion. In (32), a total of three Motion events are expressed: tulijärsakult ('came from the precipice'), pani sarved pähe ('put on its antlers') and viskas poisi õhku ('threw the boy in the air'). Again, the main verbs tuli ('came'), pani ('put') and viskas ('threw') describe the Manner of Motion, while the satellites järsakult (precipice.ABL 'from the precipice'), pähe (head.ILL 'into the head') and õhku (air.ILL 'into the air') convey the Path of Motion.

There was a wide array of clauses in which the verb did not imply movement, but were considered Motion events nevertheless, because in these specific constructions the clauses still described the movement of the Figure in relation to the Ground. For example, in (33), the verb avastama ('to discover') does not imply motion on its own, but in the context of this sentence, the Figure (e.g. sõbrad 'the friends')

\footnotetext{
3 In this sentence, the word poisi (boy.GeN) is spelled with a double 's' instead of a single 's'. However, there remains the possibility that the participant aimed at using the partitive form of the word rather than the more suitable genitive form which would make the word grammatical but not suitable in the given context.
} 
changes its location with respect to the Ground (e.g. selle it.GEN.SG), resulting in the Figure's movement to the behind of the referent of 'it'.

(33) Selle tagant avastasid sõbrad kaks toredat konna. (L1)

'Behind it, the friends discovered two lovely frogs.'

\subsection{Constructions expressing Path}

The most frequently used linguistic means for expressing Path by L1 Estonian speakers was morphological case-marking on nouns, as shown in (34). In this sentence, the satellite to the verb is the noun mets 'woods' used in the short illative. ${ }^{4}$

(34) Nad mõlemad jooksid metsa. (L1) (woods.ILL [short form]) 'They both ran into the woods.'

Postpositional phrases, as in (35), were used less than half of the times and prepositional phrases, as in (36), were only used in three occasions.

(35) Läksid nemad sïs tiigi poole. (L1) (pond.gEN towards) 'So they went towards the pond.'

(36) Ka koeral ei läinud õnneks, sest ta ... lendas samuti üle ääre. (L1) (over edge.GEN)

'The dog was also unlucky, because he ... flew over the edge as well.'

In example (35), the participant used the postposition poole ('towards') with the noun complement tiik ('pond') in genitive to express the Path of Motion. The postposition poole ('towards') occurs in the allative case, which is shown by the ending -le, and conveys trajectory. In example (36), the participant expressed the Path of Motion by using the preposition üle ('over') with the noun complement äär ('edge') in genitive.

Figure 1 shows the proportion of different linguistic means used for expressing Path found in the narratives of the control group and the learner groups. The case-marking in postpositional or prepositional phrases is not considered in the group "Case endings" indicated with light gray (dotted) columns; it only includes instances where satellite is expressed by a case-marked noun, as in majja (house. ILL 'into the house') and purgis (jar.INE 'inside the jar').

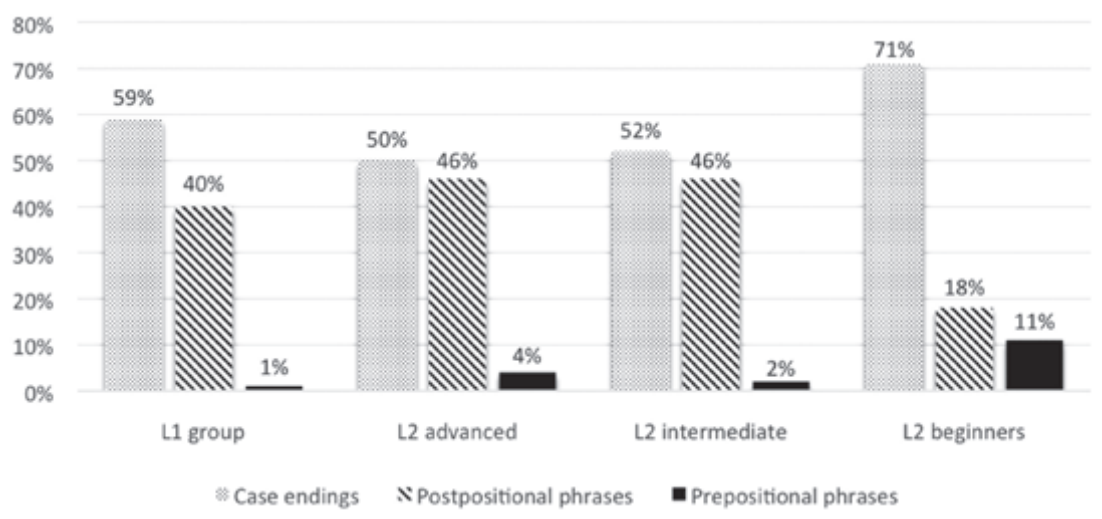

Figure 1. Linguistic means for expressing Path by group

4 This form formally coincides with the genitive metsa 'of the woods', yet in pronunciation the duration is different. 
The advanced and intermediate learners of L2 Estonian were similar to each other in expressing Path, as roughly half of the linguistic means they used were case-marked nouns (e.g. pudelis - bottle.INE 'inside the bottle') and the other half consisted of postpositional constructions (e.g. puunoti taga - log.GEN behind.INE 'behind the log'). Only $3 \%$ of the Path constructions were prepositions, as they are not very common in the Estonian language. As one could expect, the beginner group's usage of Path constructions differed from that of the L1 group most extensively. Similarly to L1, L2 advanced and L2 intermediate group, the majority (71\%) of the Path constructions used by the L2 beginner group was formed by using case-marked nouns. In all the other groups, however, case endings and postpositional phrases were more proportionally levelled (50\% and $46 \%$ respectively in the L2 advanced group), while L2 beginners differed more in using these two constructions ( $71 \%$ and $18 \%$ respectively). This difference could be explained by the fact that it might be easier for the beginner learners to simply use the nouns given next to each picture, compiling simple sentences where only a verb and a case-marked noun have been added, instead of more complex postpositional constructions. For example, under the 11th picture (see Appendix), the nouns included the words poiss ('the boy') and puu ('the tree'), so a beginner group participant used the sentence poiss vaatas puus (tree.Ine 'the boy looked in the tree') instead of the full postpositional phrase poiss vaatas puu sisse (tree.GEN inside 'the boy looked into the tree').

All Motion events found in the 'frog story' were analysed separately to see whether learner groups differed in the way they expressed them. The only notable difference was that the beginner group participants used only simple verbs which convey Motion, such as minema ('to go') when describing the act of the frog exiting the jar. When describing the same event, the intermediate and advanced learners used verbs that communicated the Manner of Motion as well, such as ronima ('to climb') or hüppama ('to jump'). This partly supports the findings of Pool and Pajusalu (2012) who found that learners in their study used verbs that only conveyed Motion and not the Manner of Motion more often than native speakers. However, as this difference between the three learner groups was only found for the single Motion event, and no other examples of this pattern were found, no conclusions can be made. Moreover, there were very few Motion events that were represented in all of the narratives, making this type of analysis rather difficult and the results inconclusive.

\subsection{Does English have an impact on expressing Motion in L2 Estonian?}

Many of the grammatical inaccuracies that occurred in the narratives of the L2 learners of Estonian seemed arbitrary and irregular, as in (37):

(37) Poiss läks välja hirvast. (out.ILL deer.ELA) (pro kukkus hirve seljast maha; back.ELA down.ILL)

Intended meaning: 'The boy fell off the deer.'

Example (37) demonstrates a construction in which no L1 pattern of expressing Motion could be detected. In the example, the inaccurate usage of hirve seljast 
maha ('off the deer's back') is not caused by the impact of the learner's first language, as no connection between the grammatically inaccurate Estonian phrase läks välja hirvast ('went out of the deer') and the grammatically accurate English phrase 'fell off the deer' can be detected. The only possible L1 thinking pattern may be seen in the use of wrong word order in this phrase: the intended postpositional phrase (hirvest välja - deer.ELA out.ILL) is constructed as a prepositional phrase (välja hirvest - out.ILL deer.ELA) which is a common means of expressing Motion in English. Moreover, since the preposition 'off' has a rather wide use in English, it may be difficult for the L2 learner of Estonian to choose an appropriate postposition from the large number of Estonian equivalents.

However, there was also a considerable amount of ungrammatical clauses in which the influence of English could be detected, as in (38) and (39):

(38) Poiss ronib puu üles. (tree.gen up.ILL) (pro puu otsa; tree.gEN upon.ILL) Intended meaning: 'The boy climbs up the tree.'

(39) Nad panid Heino puust välja kukkuma. (tree.ELA out.ILL) (pro puu otsast alla; tree.GEN upon.ELA down.ILL) Intended meaning: 'They made Heino fall out of the tree.'

In example (38), the participant expressed the act of climbing up a tree, relying on the expression of Motion in English. Translated directly from the participant's L1, the phrase 'climbs up the tree' results in the phrase ronib puu üles that is not used in Estonian, while the actual intended phrase uses a different word for a satellite, that is, ronib puu otsa ('climbs upon the tree'). Likewise, in (39) the subject uses a familiar construction of his L1 'fall out of the tree' and translates it directly into L2 Estonian, forming an inaccurate phrase puust välja kukkuma instead of the phrase puu otsast alla kukkuma ('fall down from upon the tree'). That is, the wrong satellite has been chosen to express Path, even though it is in the correct case form.

(40) Mõlemad ronivad puunoti taga. (log.Gen behind.INE) (pro puunoti taha; log.GEN behind.ILL)

Intended meaning: 'Both climb behind the log.'

Example (40) illustrates another way English can affect describing Motion events in Estonian. English uses the same preposition 'behind' for expressing both location and motion, while Estonian distinguishes between these notions by using the corresponding postposition in two case forms: taga (behind.INE 'in behind') and taha (behind.ILL 'to behind'). In this Motion event, the participant aimed at describing motion rather than the continuation of a stationary location. However, when not used to differentiating between these ideas morphologically, the word taga (behind. INE) may get confused with taha (behind.ILL), even if the verb ronima ('to climb') implies movement instead of location.

In example (41), the subject used the word pudel ('bottle') in the inessive case as opposed to the more common illative case. This could be explained by the fact that in English, the phrase 'inside the bottle' directly translates to pudelis in Estonian, which is not appropriate in the present context described by this particular clause. The appropriate Estonian case form, the illative pudelisse directly translates to a contextually flawed phrase in English, 'into the bottle', which may have prevented the subject from using it. 
(41) Koer, kelle pea oli pudelis kinni jäänud ... (bottle.INE) (pro pudelisse; bottle.ILL)

Intended meaning: 'The dog, who had gotten his head stuck inside the bottle ...'

There seemed to be two main types of L1-ifluenced inaccuracies in the learners' narratives when expressing Path: choosing the inappropriate postpositions (as in 38 ) and choosing the inappropriate case-marking (as in 40). Both of these types appear to be a result of direct translation from the participants' L1. As expected according to Talmy's (2000) classification and further confirmed by Eifring and Theil (2005), there appeared no differences in foregrounding and backgrounding information between the L1 and L2 group, as both Estonian and English qualify as satellite-framed languages.

Figure 2 shows that although the highest number (32) of ungrammatical phrases occurred in the beginner group, they were mostly not L1-influenced.

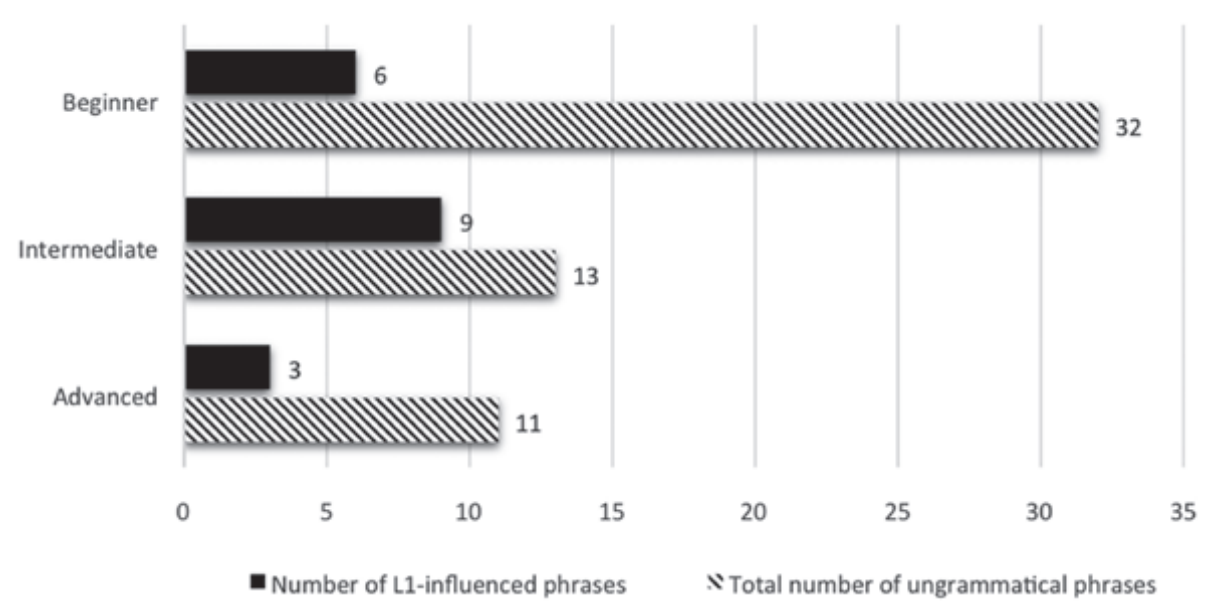

Figure 2. Number of L1-influenced phrases compared to the total number of ungrammatical phrases

Less than one fifth of the beginner group's incorrect constructions were influenced by their L1. These L1-influenced constructions generally occurred in prepositional phrases where postpositional phrases would be more appropriate. This is illustrated in example (42), in which the participant reversed the word order, making the Estonian phrase kivi kõrvale more similar to its equivalent in English ("next to the rock'), resulting in kõrval kivi. In addition, the same issue occurred as in (40) and (41): Estonian uses two different case forms kõrval (next.ADE) and kõrvale (next.ALL) for expressing location and motion respectively, while English uses the prepositional phrase 'next to' on both occasions, making it difficult for the learner to choose the correct form.

(42) Poiss jalutame kõrval kivi ... (next to.ADE rock.NOM) (pro jalutab; kivi kõrvale; rock.GEN next to.ALL)

Intended meaning: 'The boy walked next to the rock.'

The relative frequency of using L1-influenced patterns when expressing Motion was highest in the intermediate group (69\%), occurring mostly in postpositional phrases. In the advanced group, L1-influenced constructions occurred 33\% more than in the beginner group, but $61 \%$ less than in the intermediate group. The reason 
L1 influences occurred less often (27\%) in the advanced group than the intermediate group may lie in the advanced learners' ability to already think in their second language and adapt to its grammar rules rather than relying on their first language and trying to adapt Estonian to its rules instead.

The low number (19\%) of L1-influenced constructions among beginners is most likely not an indication of their ability to ignore the thinking patters of their L1, as is likely the case with the advanced group participants. The beginner learners simply lack the lexical means to recognise the parallels between their L1 and L2. That is, when expressing themselves, the participants of the beginner group seem to focus mainly on finding the suitable words rather than using them in their correct form. Unlike the advanced group, the beginner group appears to be not yet familiarised enough with the Estonian rules of using case markers or adpositional constructions to associate them with their English equivalents; this results in expressions that show no obvious link to their first language.

This argumentation could also explain the frequent occurrence of L1-influenced phrases in the narratives of the intermediate group. This group already has a wider range of vocabulary and seems to be more aware of the grammar rules of Estonian. However, the connection with Estonian is still not as strong as for the advanced learners. This means that when forming Motion events, they rely heavily on the language they know best and adapt its rules to Estonian, resulting in the use of L1 constructions in their L2.

The results of this study partly support the findings of Cadierno and Ruiz (2006) who suggested that L1 thinking-for-speaking patterns have a rather limited role in advanced adult language learners and hypothesised that the role of these L1 thinking patterns may be more significant when the language acquisition is still in the initial or intermediate stages. This study, however, shows that in the initial stages of acquiring an L2, learners' expression of Motion is mostly not connected to their L1 thinking patterns, as the learners are not fluent enough in their second language to seek applicable support from their first language. That is, native English speakers who are learning L2 Estonian and are currently on the beginner level, may find it difficult to even notice the connection between certain English prepositions and the corresponding Estonian case-marking, because they are still familiarising themselves with the vocabulary and grammar rules of their L2. This in turn leads to a low number of L1-influenced constructions, since the familiar L1 constructions cannot be transferred and adapted to their L2 to create the conditions for these inaccuracies to occur.

\section{Conclusion}

This study aimed to determine whether and how native speakers of English are influenced by their L1 when expressing Motion in L2 Estonian. The study intended to find answers to the questions whether native speakers of English and native speakers of Estonian differ in the number of Motion events they describe in their Estonian narratives; and what kind of linguistic means are most frequently used by native English speakers when expressing Path of Motion in Estonian, and whether they differ from those of native Estonian speakers.

The average number of Motion events found in the narratives of the experimental group and the control group differed: there were 26 Motion events in the 
L2 group and 31 in the L1 group. The number of Motion events was lower in the L2 group, because of the beginner group narratives were low on clauses containing Motion events, in turn lowering the average of the whole L2 group.

The most frequently used linguistic means for expressing Path of Motion among the control group was morphologically case-marked nouns, which were used a little more than half of the times. Postpositional constructions were used a little less than half of the times and prepositional phrases hardly occurred at all. The advanced and intermediate learners did not contrast with the L1 group's usage of constructions as much as the participants in the beginner group, who exhibited a larger difference between the number of times they used case markers and postpositional constructions. In addition, they used prepositional constructions more than the two other learner groups. However, these prepositional constructions were simply postpositional constructions with ungrammatical constituent order.

This study shows that English adult learners of L2 Estonian often misuse linguistic elements that are not as common for expressing Motion in their native language (e.g. case markers and postpositional constructions). However, the amount of these inaccuracies differed between the three groups of learners: as expected, the highest number of incorrect constructions occurred in the narratives of the beginner group and the lowest number in the advanced group. The number of inaccurate constructions that occurred in the intermediate group was slightly higher than that of the advanced group but lower than that of the beginner group. The type of these phrases was also noteworthy: while most of the incorrect constructions used by the intermediate group could be accounted for the influence of their L1, the inaccuracies present in the narratives of the advanced group and the beginner group were generally not L1-influenced. The small percentage (27\%) of L1-influenced patterns among the Motion events of the advanced group can be explained by these participants' ability to already think in Estonian, without having to transfer the rules of their first language to fit the target language. As opposed to the advanced group, the beginner group is not yet experienced enough in forming Estonian case endings or adpositional constructions to associate them with their English equivalents, resulting in a small percentage (19\%) of phrases that show an apparent connection to the grammar rules of their first language. The percentage of L1-influenced patterns is the highest (69\%) among the intermediate group, since they have already obtained a large Estonian vocabulary and are familiar with the rules of forming the necessary constructions for expressing Motion, but still look for support in their first language, which leads to inaccurate constructions, in which the grammar rules of English have been utilised in Estonian.

Since the sample size of this study was not very large, this topic could be further examined with a larger number of participants to minimize the impact that individual peculiarities may have on the results. As mentioned by Pool and Pajusalu (2012: 179), it is difficult to find learners of L2 Estonian, since they are rather scarce in number. Further studies with a greater number of participants would help determine when the transition from being influenced by one's L1 thinking-for-speaking patterns to being able to successfully switch between one's L1 and L2 exactly occurs on the timeline of language acquisition. Moreover, to shed light on the topic of native English speakers acquiring Motion in L2 Estonian, the process of how native speakers of English acquire Motion verbs in Estonian could be examined. It would 
be interesting to see whether the findings would support those of Pool and Pajusalu (2010) who found that compared to native Estonian speakers, Russian learners of L2 Estonian used more Motion verbs that described only Motion and considerably less Motion verbs where the Manner of Motion was expressed as well.

\section{References}

Cadierno, Teresa; Ruiz, Lucas 2006. Motion events in Spanish L2 acquisition. - Annual Review of Cognitive Linguistics, 4 (1), 183-216. http://dx.doi.org/10.1075/arcl.4.08cad Eastwood, John 2009. Oxford Guide to English Grammar. Oxford: Oxford University Press. Eifring, Halvor; Theil, Rolf 2005. Linguistics for Students of Asian and African Languages. http://www.uio.no/studier/emner/hf/ikos/EXFACo3-AAS/ho5/larestoff/linguistics/ (24.11.2014).

Erelt, Mati (Ed.) 2003. Estonian Language. Linguistica Uralica Supplementary Series 1. Tallinn: Estonian Academy Publishers.

Erelt, Mati; Kasik, Reet; Metslang, Helle; Rajandi, Henno; Ross, Kristiina; Saari, Henn; Tael, Kaja; Vare, Silvi 1993. Eesti keele grammatika. II. Süntaks. Trükki toimetanud Mati Erelt (peatoimetajana), Tiiu Erelt, Henn Saari, Ülle Viks. Tallinn: Eesti Teaduste Akadeemia, Keele ja Kirjanduse Instituut.

Hickmann, Maya; Hendriks, Henriëtte 2010. Typological constraints on the acquisition of spatial language in French and English. - Cognitive Linguistics, 21 (2), 189-215. http://dx.doi.org/10.1515/COGL.2010.007

Mayer, Mercer 1969. Frog, where are you? New York: The Dial Press.

Navarro, Samuel; Nicoladis, Elena 2005. Describing motion events in adult L2 Spanish narratives. - Davind Eddington (Ed.), Selected Proceedings of the 6th Conference on the Acquisition of Spanish and Portuguese as First and Second Languages. Somerville, MA: Cascadilla Proceedings Project, 102-107.

Pajusalu, Renate; Kahusk, Neeme; Orav, Heili; Veismann, Ann; Vider, Kadri; Õim, Haldur 2013. The encoding of motion event in Estonian. - Mila Vulchanova, Emile van der Zee (Eds.), Motion Encoding in Language and Space. Oxford: Oxford University Press, 44-66.

Pool, Raili; Pajusalu, Renate 2012. Liikumissündmused eesti keele õppijate kirjalikes narratiivides. - The Journal of Estonian and Finno-Ugric Linguistics, 3 (2), 153-182.

Talmy, Leonard 2000. Toward a Cognitive Semantics: Vol. II: Typology and Process in Concept Structuring. Cambridge, MA: MIT Press.

Talmy, Leonard 2007. Lexical Typologies. - Timothy Shopen (Ed.), Language Typology and Syntactic Description: Vol. III: Grammatical Categories and the Lexicon. New York: Cambridge University Press, 66-168. http://dx.doi.org/10.1017/ cbo9780511618437.002

Taremaa, Piia 2013. Fictive and actual motion in Estonian: Encoding space. - SKY Journal of Linguistics, 26, 151-183.

Liis Nelis, a graduate of Tallinn University, the department of English Studies.

Narva mnt 25, 10120 Tallinn, Estonia

liis.liisnelis@gmail.com

Merilin Miljan (Tallinn University, University of Tartu), lecturer in linguistics at the department of English Studies at Tallinn University, a researcher at the University of Tartu. Her research interests focus on morphosyntax in linguistic theories and psycholinguistics.

Narva mnt 25, 10120 Tallinn, Estonia

merilin.miljan@tlu.ee 
Appendix. Frog, where are you? (Mayer 1969)
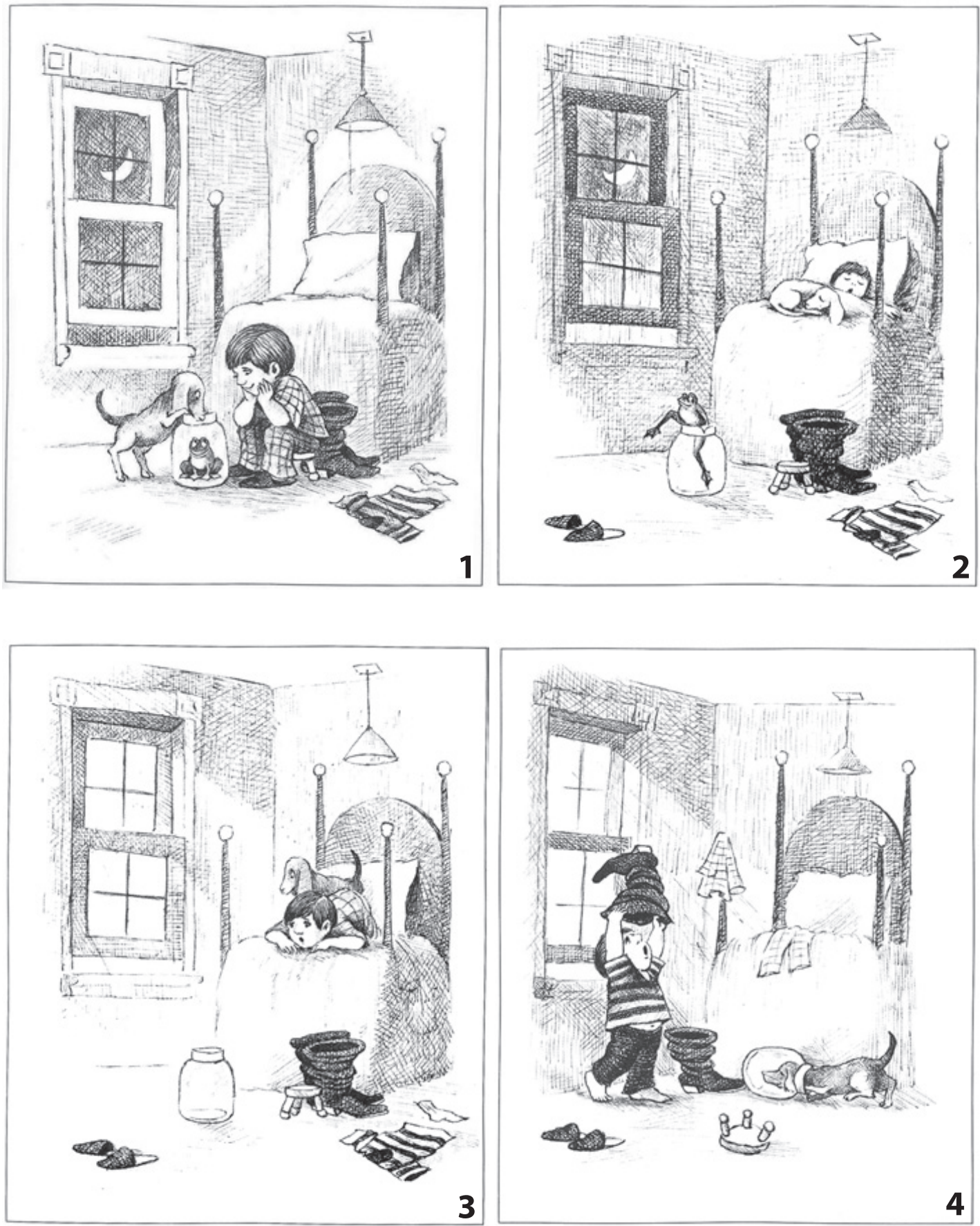

Nouns: POISS, KOER, PURK, SAABAS 

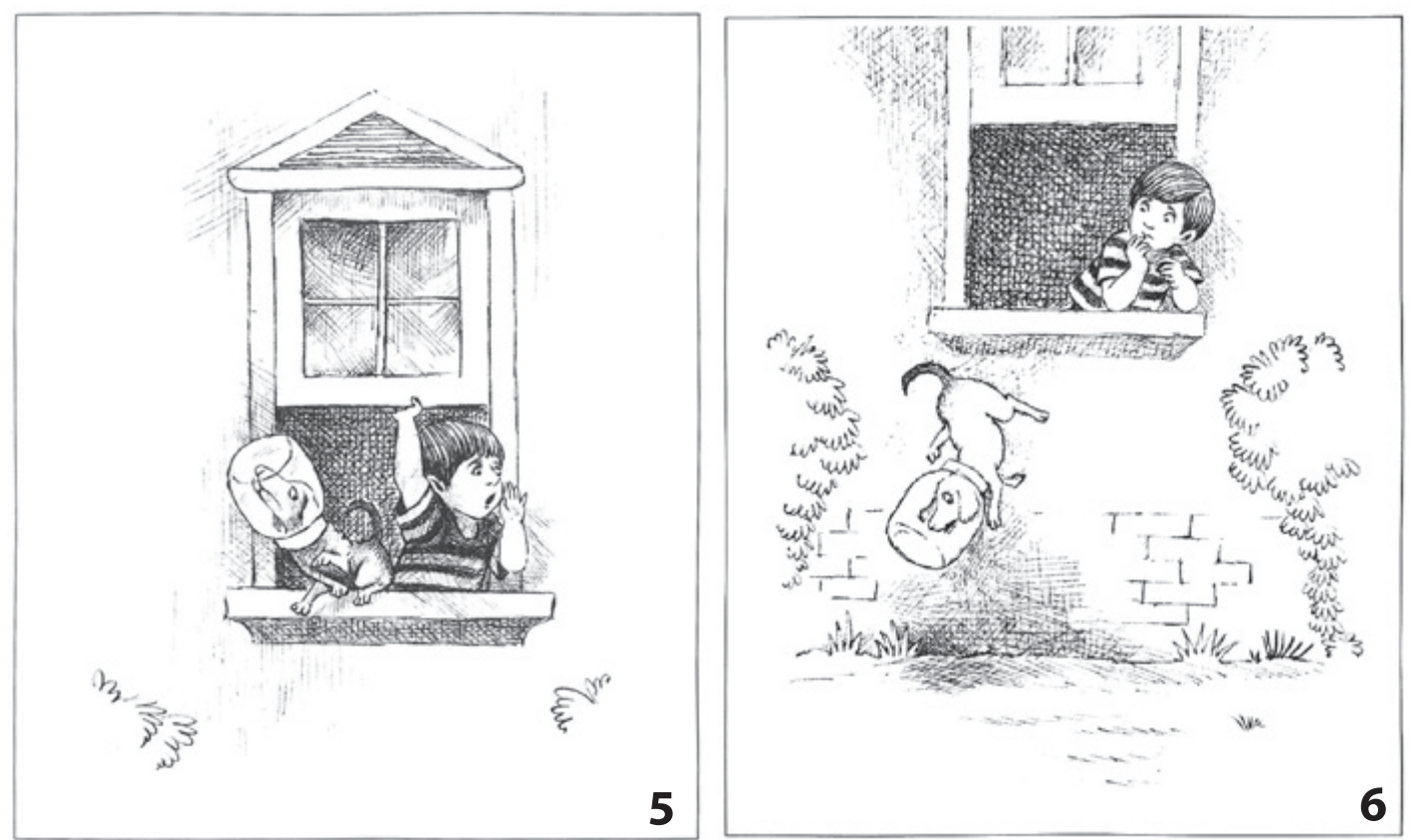

Nouns: POISS, KOER, AKEN

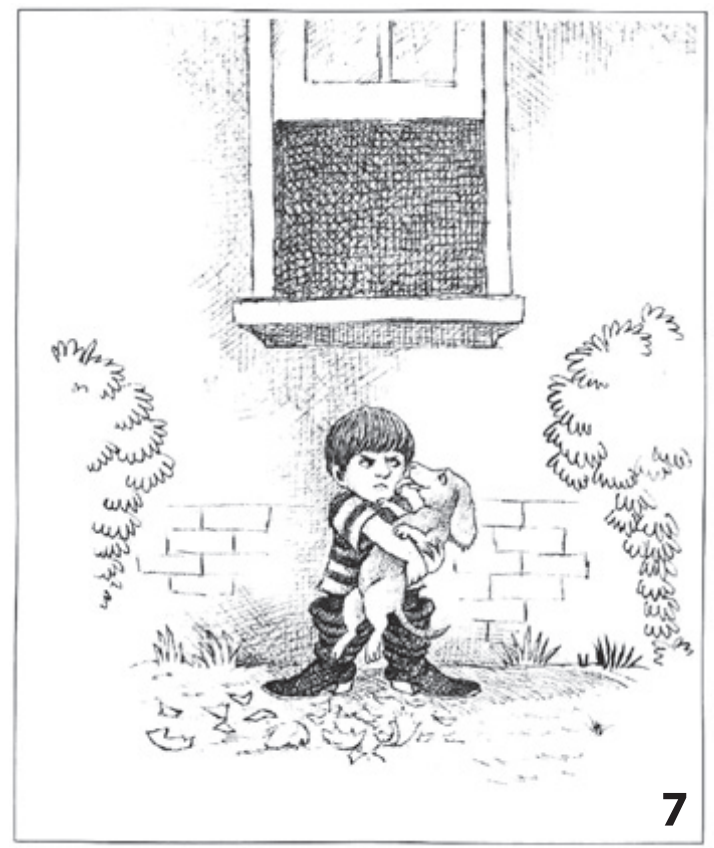

Nouns: POISS, KOER 


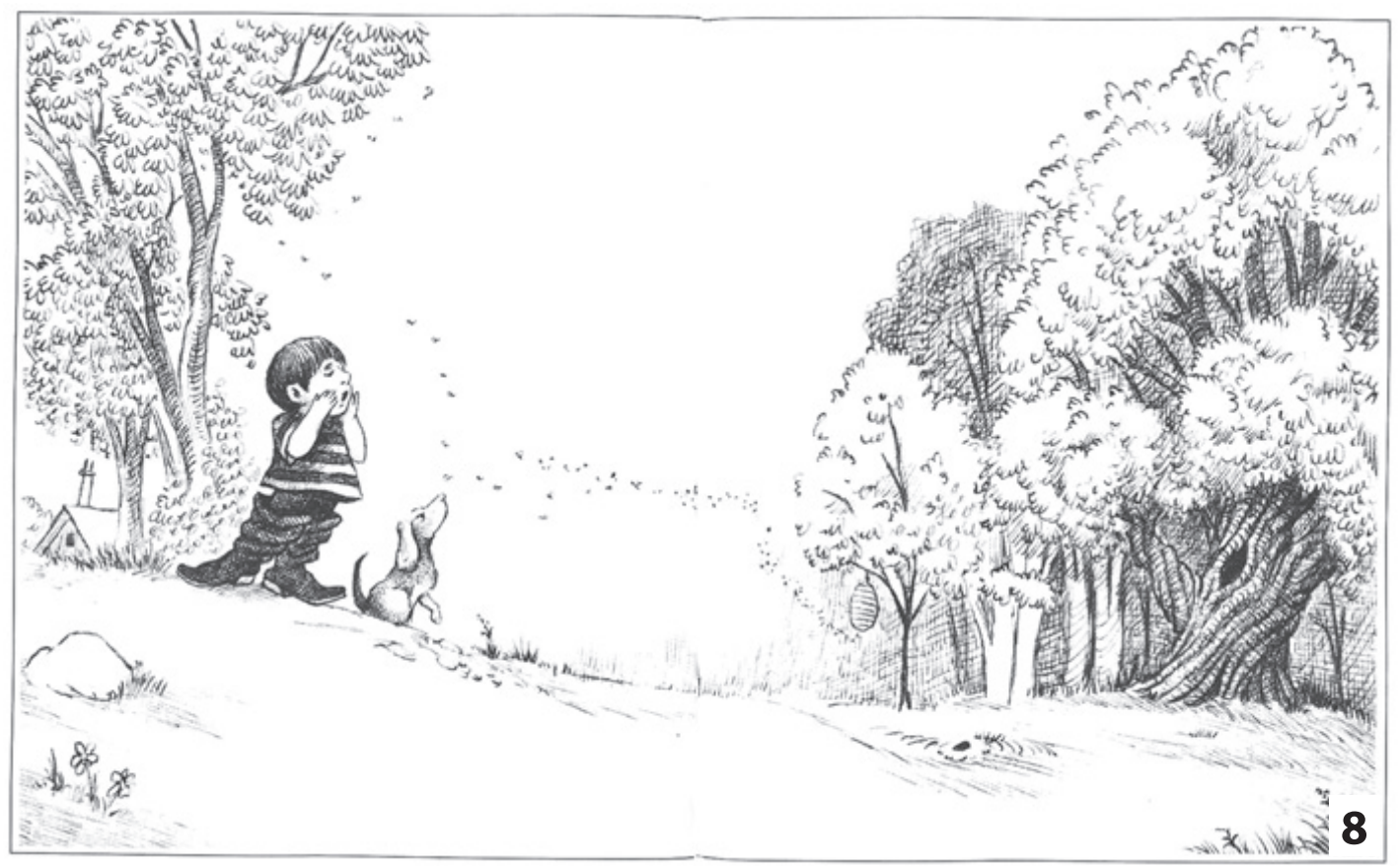

Nouns: POISS, KOER, METS
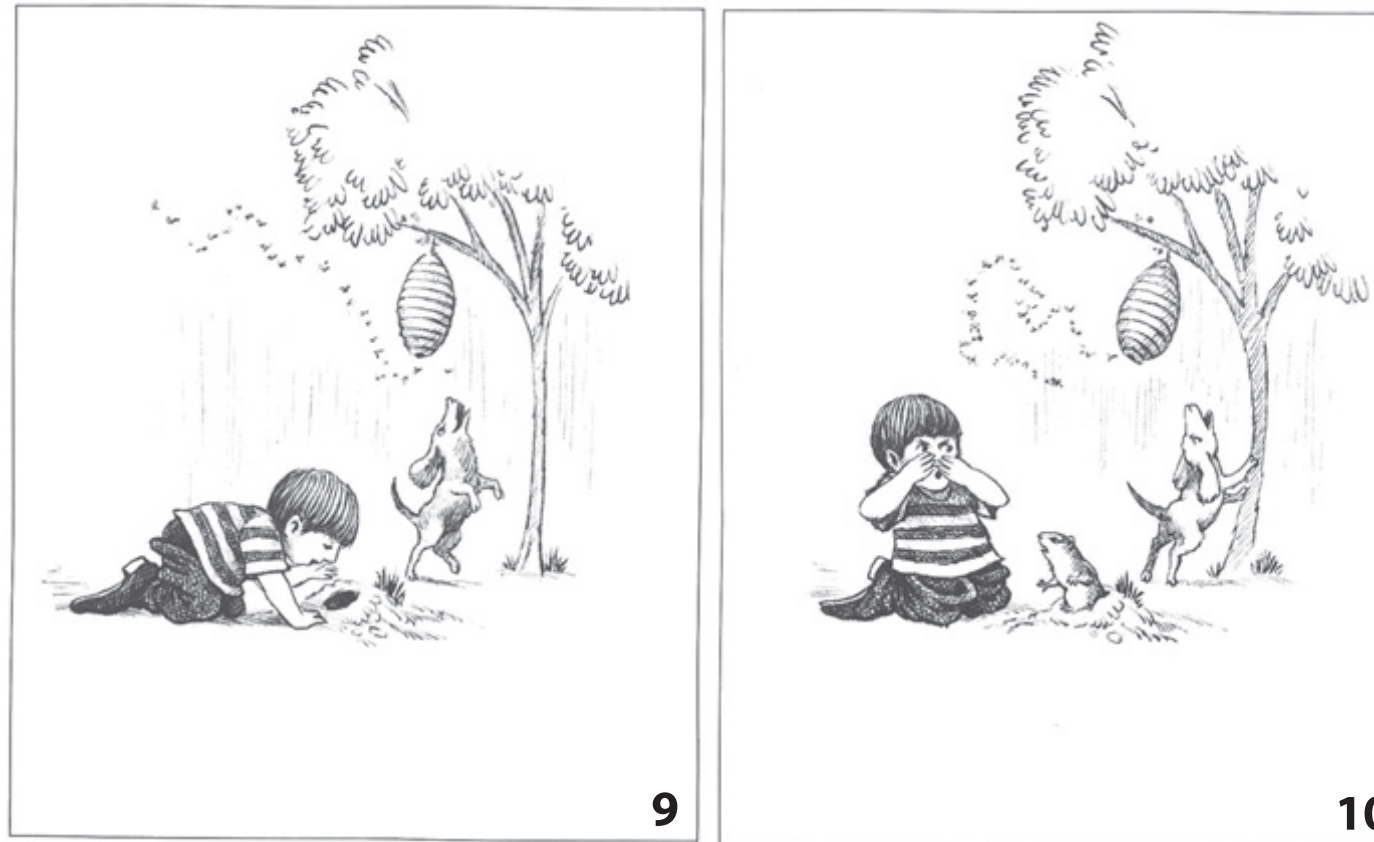

Nouns: POISS, KOER, MULLAMUTT, MESILASED 


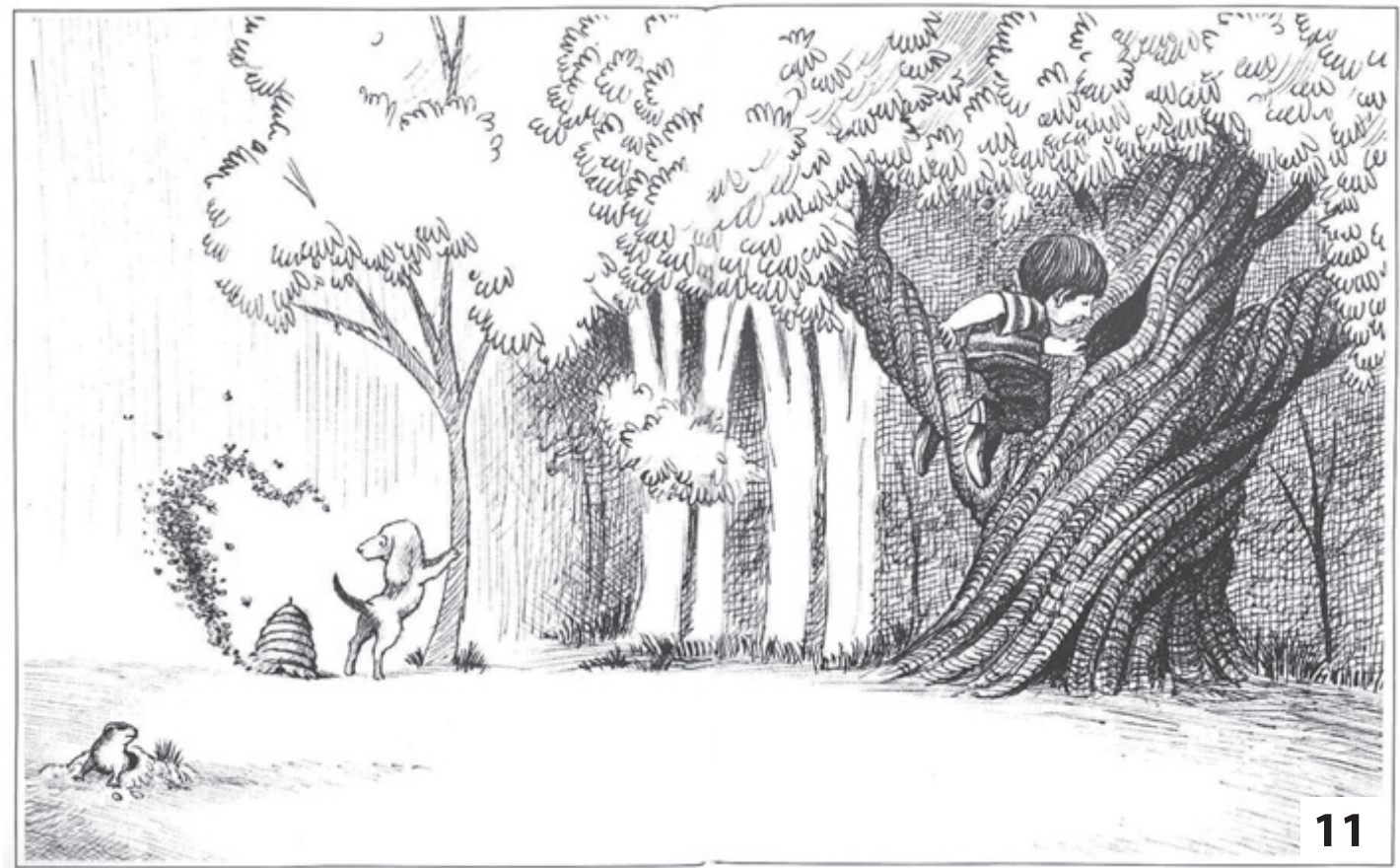

Nouns: POISS, KOER, MULLAMUTT, MESILASED, PUU

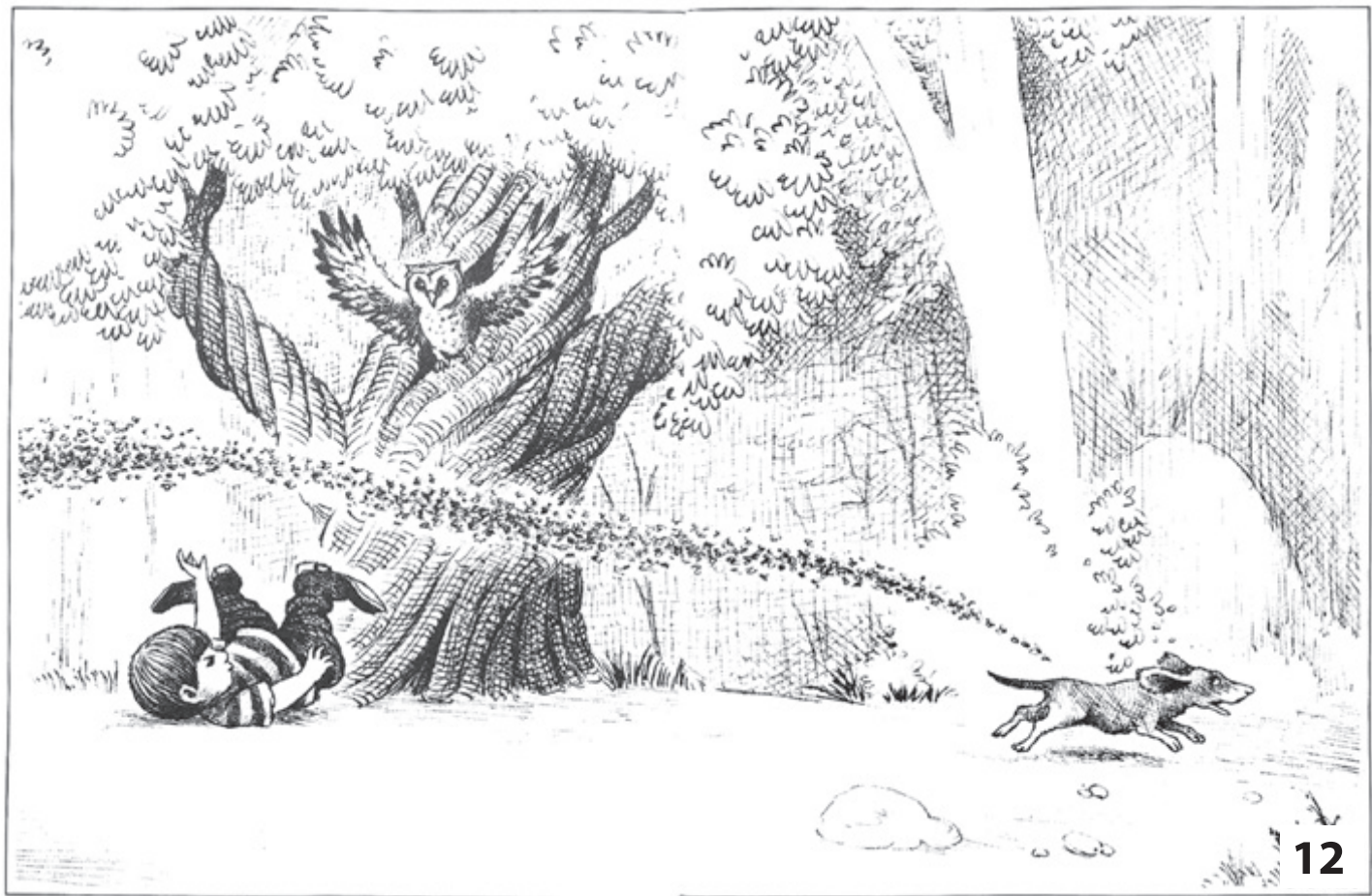

Nouns: POISS, KOER, MESILASED, PUU, ÖÖKULL 

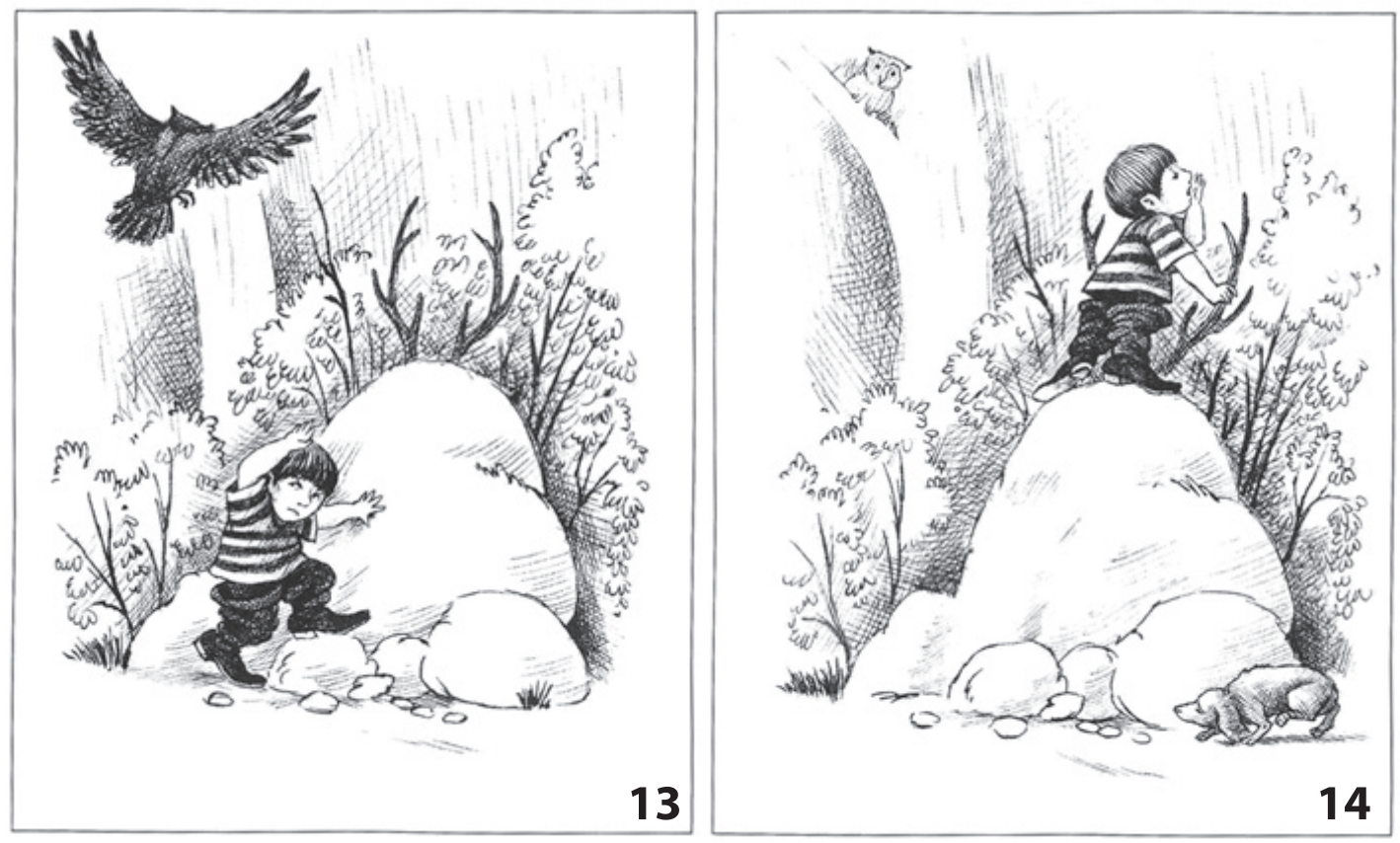

Nouns: POISS, KOER, ÖÖKULL, KIVI, SARVED
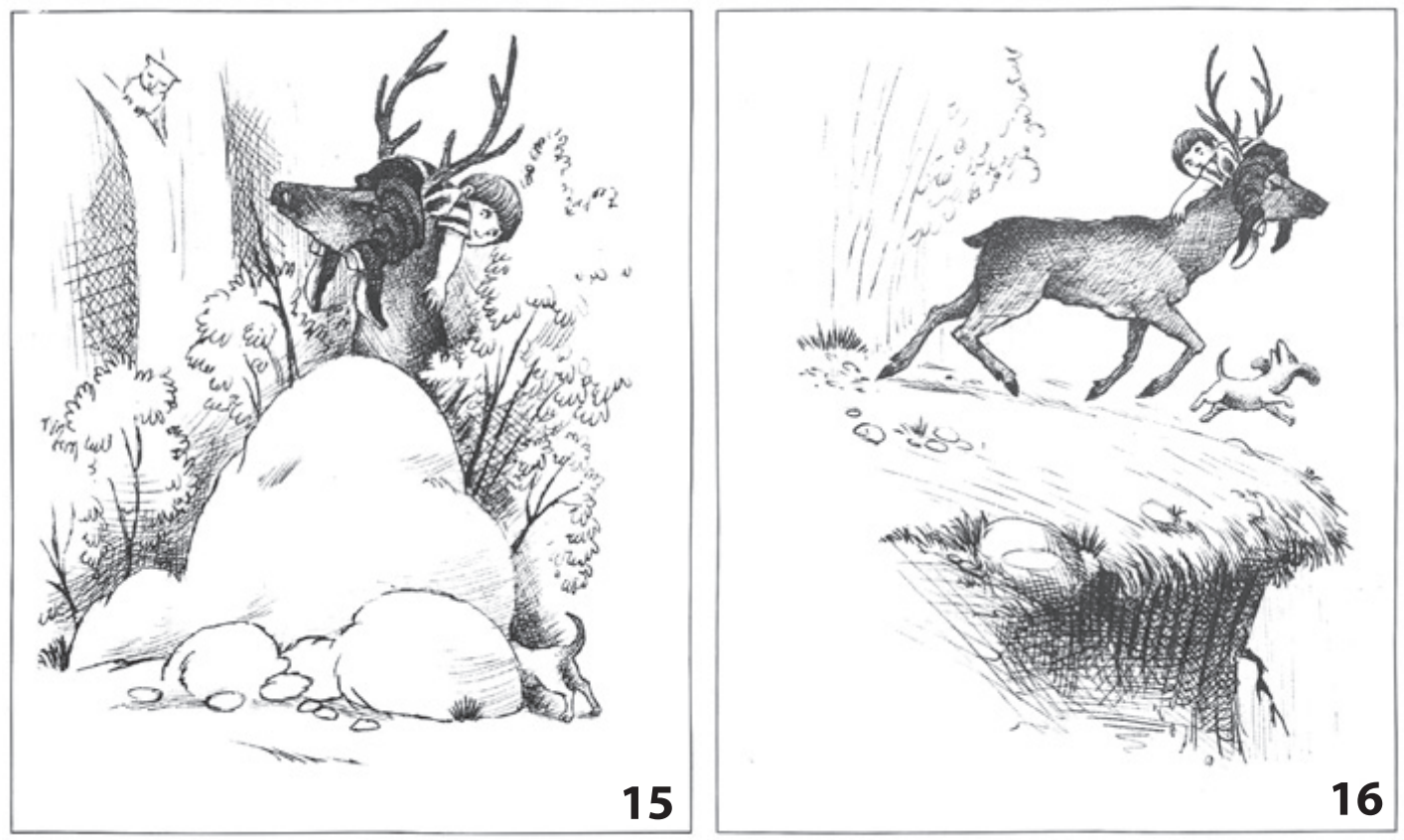

Nouns: POISS, KOER, ÖÖKULL, HIRV, SARVED, JÄRSAK 


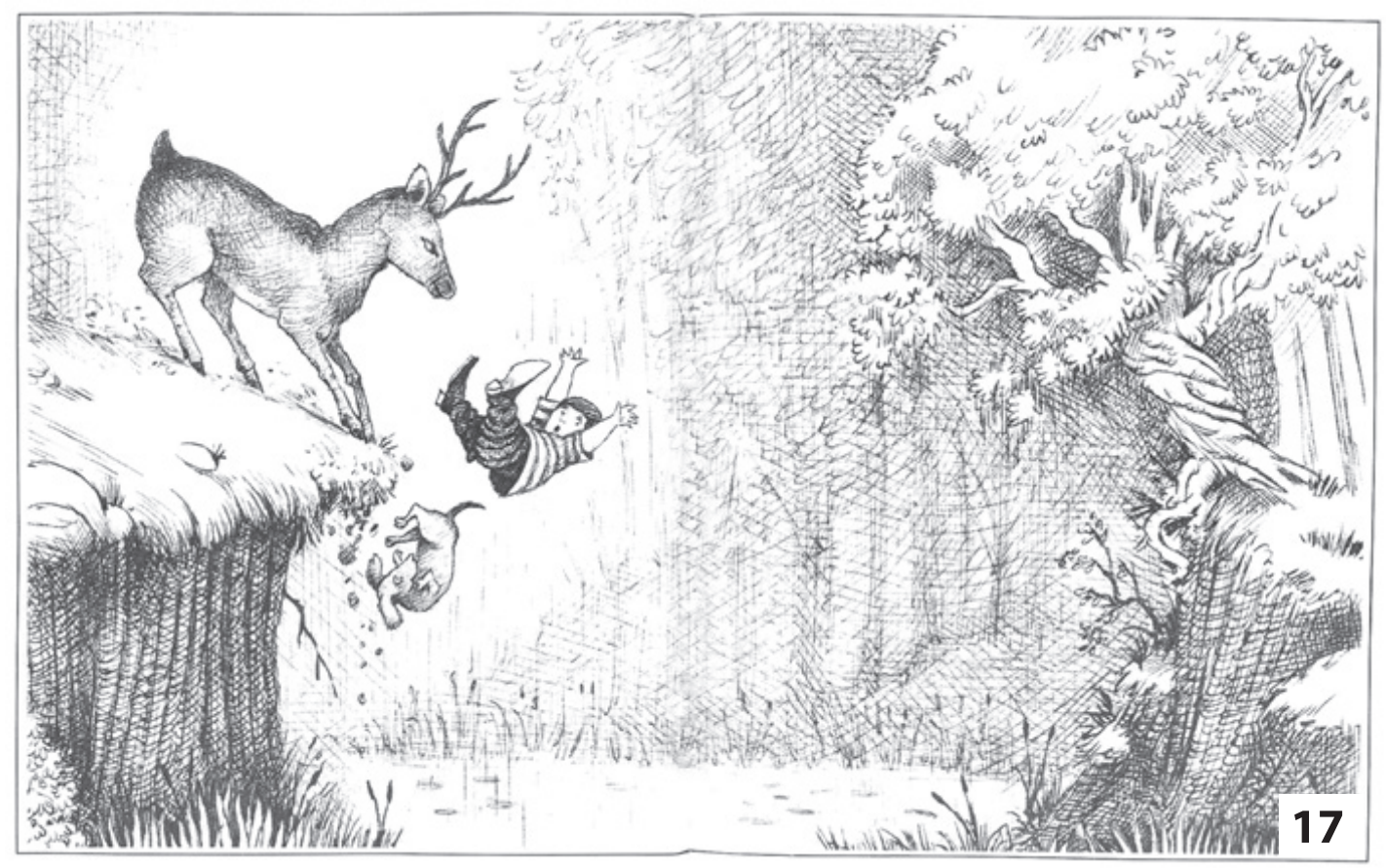

Nouns: POISS, KOER, HIRV, JÄRSAK
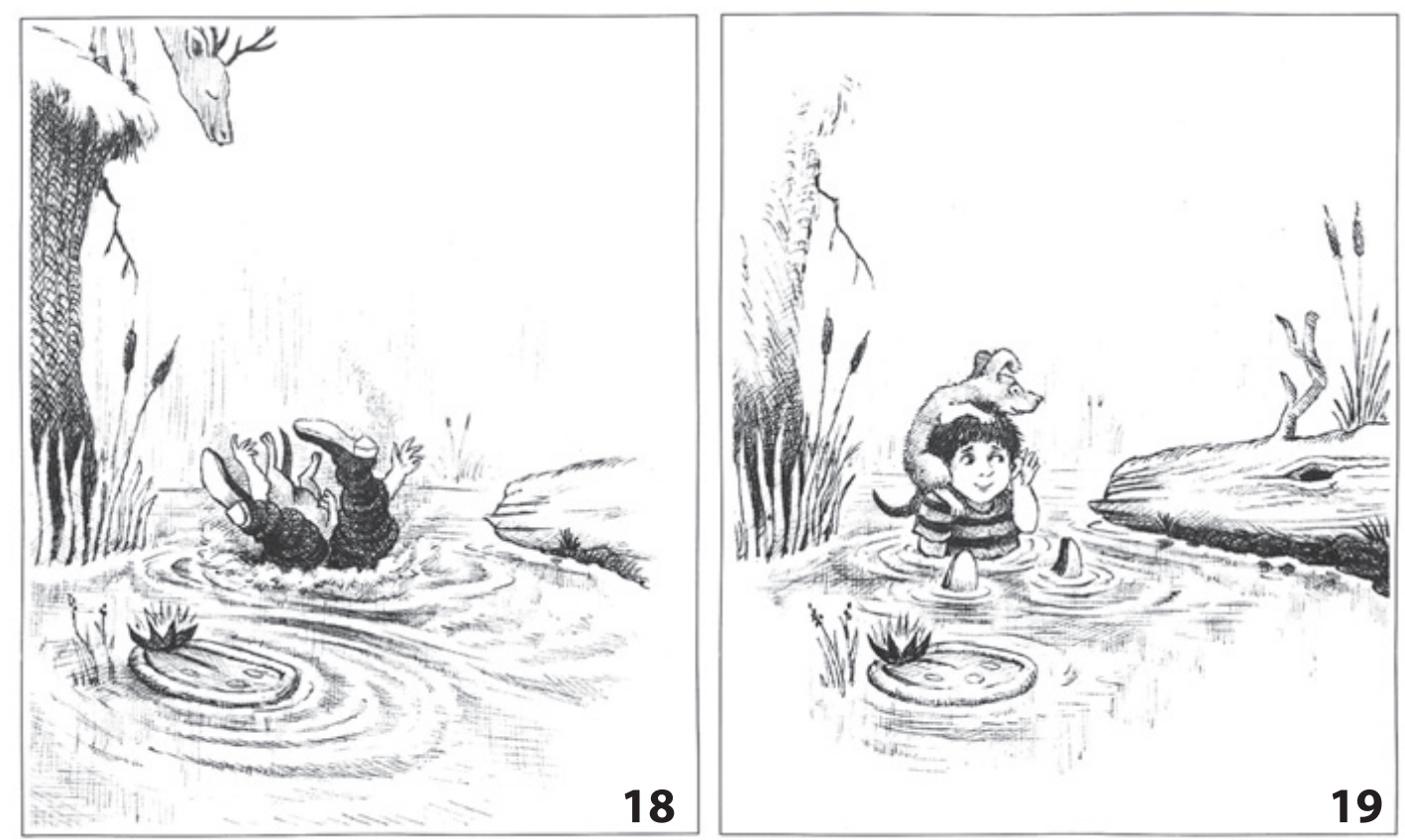

Nouns: POISS, KOER, VESI 


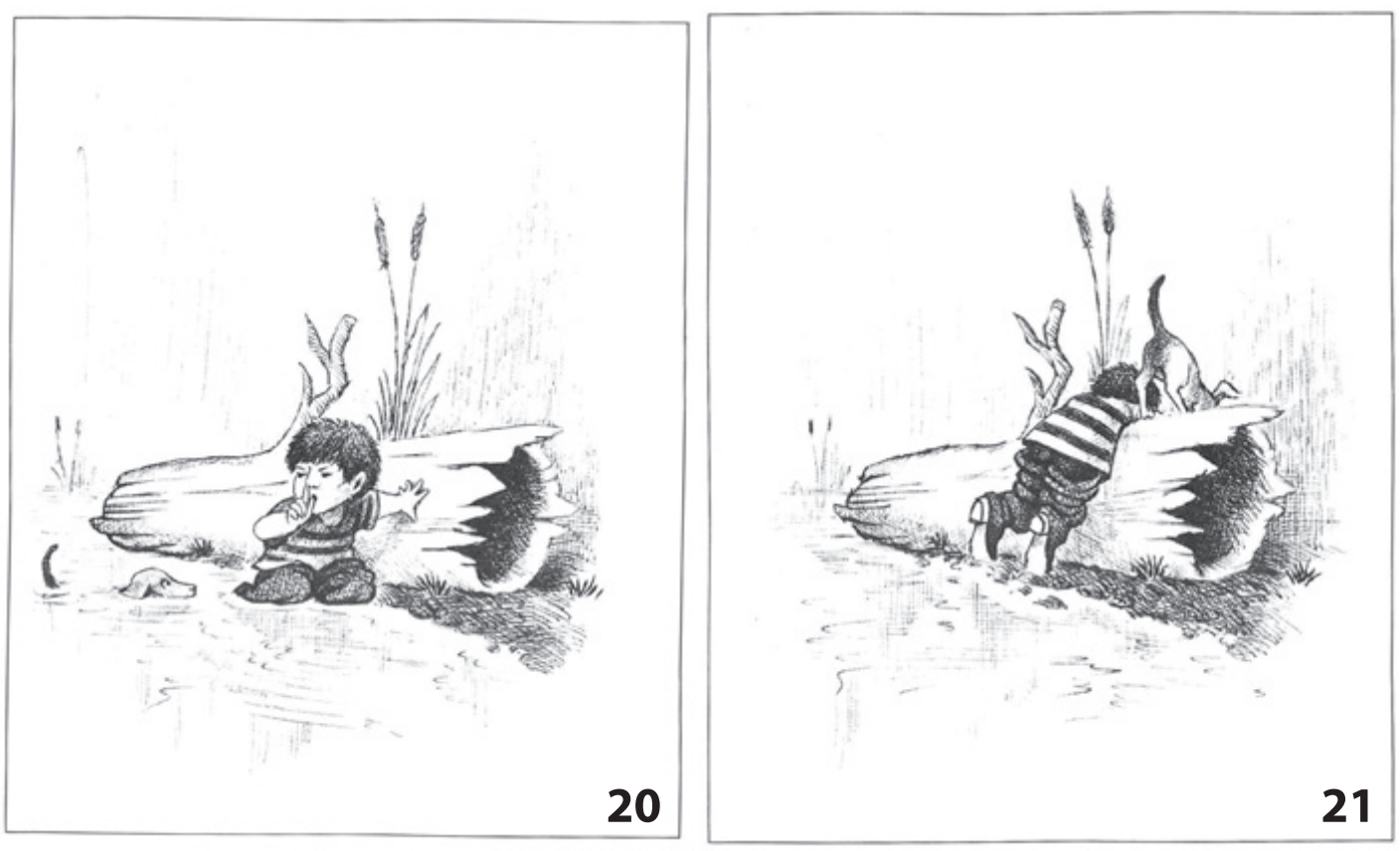

Nouns: POISS, KOER, PUUNOTT
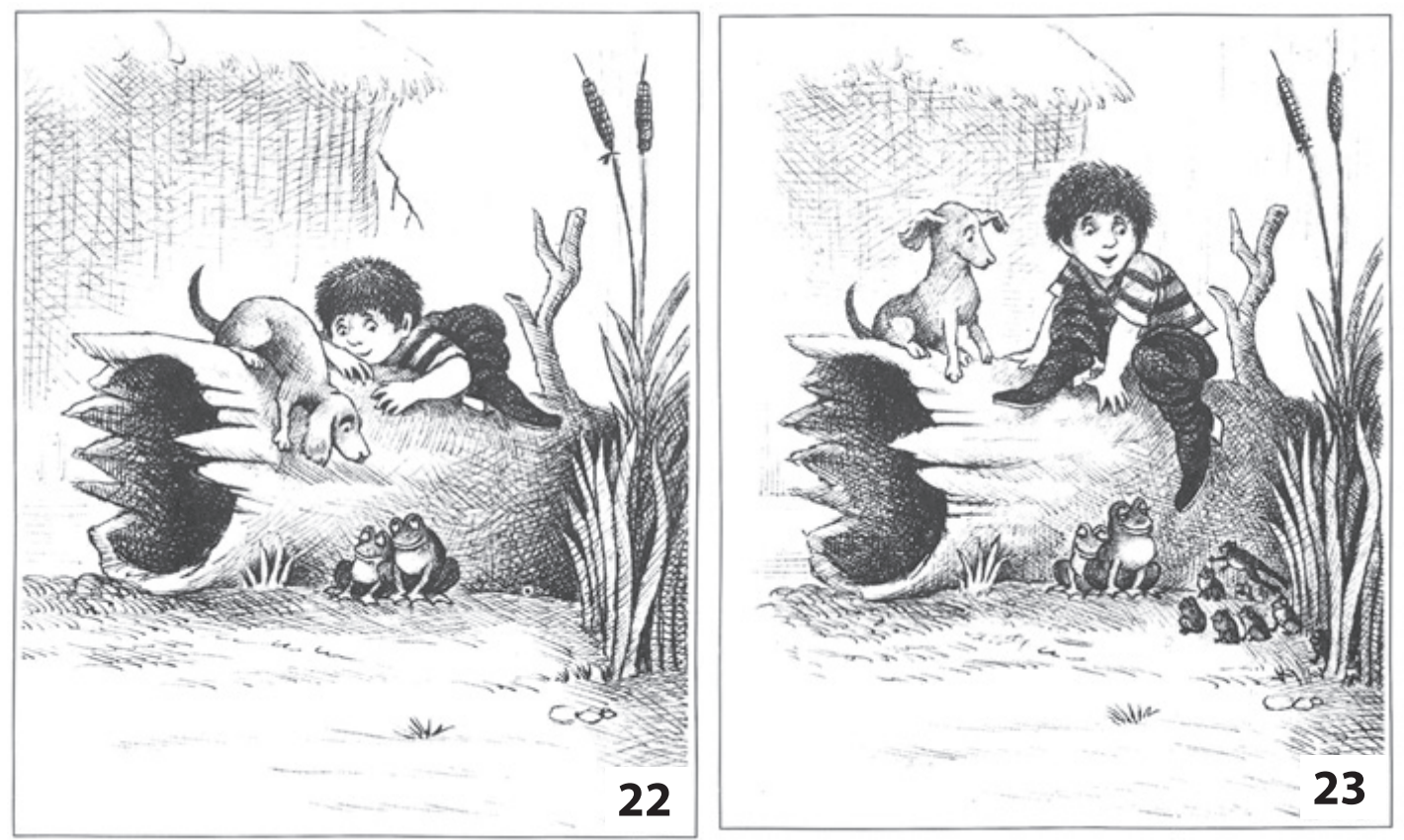

Nouns: POISS, KOER, PUUNOTT, KONN 


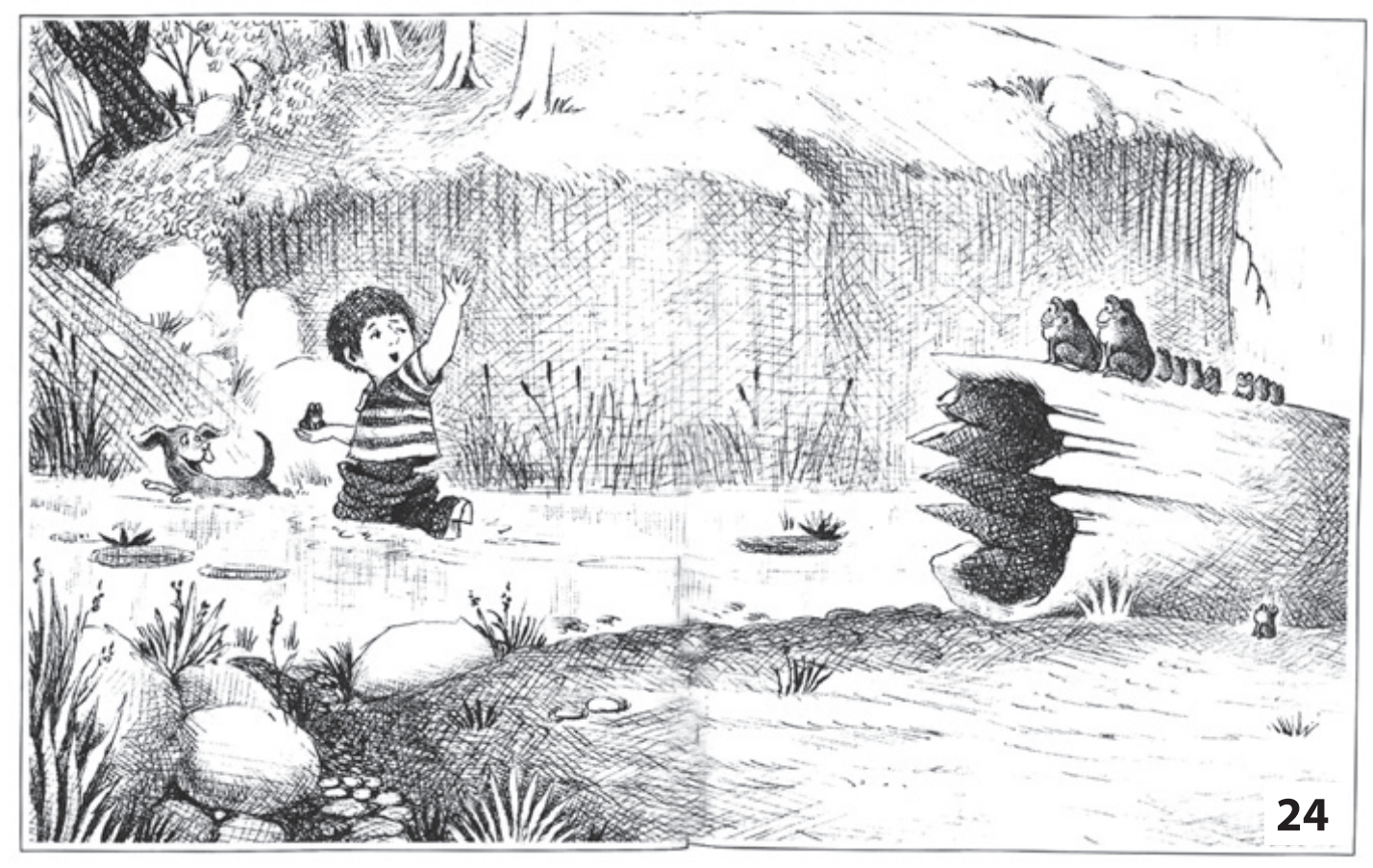

Nouns: POISS, KOER, PUUNOTT, KONN 


\title{
LIKUMISSÜNDMUSTE OMANDAMINE EESTI KEELES TEISE KEELENA
}

\author{
Liis Nelis ${ }^{1}$, Merilin Miljan ${ }^{1,2}$ \\ Tallinna Ülikool ${ }^{1}$, Tartu Ülikool ${ }^{2}$
}

Käesoleva artikli eesmärgiks oli selgitada välja, kas ja kuidas mõjutab inglise keelt emakeelena kõnelevate inimeste esimene keel liikumissündmuste väljendamist eesti keeles. Talmy (2000) teooriale toetudes võib väita, et nimetatud keeled on tüpoloogiliselt sarnased, st satelliidikeeled, milles liikumisteed väljendatakse verbisatelliitide abil. Kasutatavad verbisatelliidid erinevad neis keeltes aga oluliselt: eesti keeles kasutatakse liikumistee väljendamiseks käändelõppe ning tagasõnu, inglise keeles peamiselt eessõnu. Uurimisküsimustele vastuste leidmiseks viidi läbi eksperiment 11 inglise keelt emakeelena kõneleva isikuga, mille käigus paluti neil kirjutada lühike eestikeelne tekst Mayer’i (1969) “Frog, where are you?” piltide põhjal.

Töö tulemused toetavad püstitatud hüpoteesi: inglise emakeelega eesti keele õppijad eksivad liikumissündmusi kirjeldades sageli selliste keeleliste elementide kasutamisel, mis ei ole omased nende esimesele keelele (näiteks käändelõpud ning tagasõnad). Ootuspäraselt esines kõige enam nimetatud eksimusi algajate grupis ning kõige vähem edasijõudnute grupis. Liikumissündmuste analüüsi tulemusena võib väita, et alg- ja edasijõudnute tasemel esineb emakeele mõjutustega vigu kõige vähem ning kesktasemel kõige enam. Edasijõudnute tasemel eesti keele õppijad teevad vähe emakeele mõjutustega vigu, kuna tunnevad piisavalt hästi eesti keele grammatikareegleid ning liikumissündmuste väljendamiseks kasutatavaid konstruktsioone. Algtasemel eesti keele õppijad aga ei ole veel piisavalt hästi vajalike konstruktsioonide kasutamisreeglitega kursis, mistõttu on neil keeruline leida ka ühenduskohti oma emakeelega. Seega tekib vähe selliseid eksimusi, mida saaks seostada inglise keele reeglite eesti keelde mugandamisega. Kesktasemel eesti keele õppijate narratiivides leidus esimese keele mõjutustega vigu kõige enam, kuna selle grupi esindajad tundsid juba piisavalt hästi käändelõppude ja tagasõna konstrukstioonide moodutamise reegleid, et neid oma emakeele vastavate elementidega seostada. Siiski jäid nad tihti hätta nende reeglite õige kasutamisega, mistõttu püüdsid oma emakeeles kasutatavaid keelelisi vahendeid eesti keelega kohandada.

Võtmesõnad: teise keele omandamine, liikumissündmus, inglise keel esimese keelena, eesti keel teise keelena 